\title{
Current status of Korean streams and exploring areas with high necessity for stream structure restoration
}

\author{
Kwang-Seuk Jeong ${ }^{1}$, Han-Gook Kim ${ }^{2}$, Jong-Chul Jeong ${ }^{3}$, Dong-Kyun Kim ${ }^{4}$, Hyun-Woo Kim ${ }^{5}$, \\ Jae-Kwan Lee ${ }^{6}$, Jong-Min $\mathrm{Oh}^{7}$ and Gea-Jae Joo ${ }^{1 *}$ \\ 1 Department of Biological Science, Pusan National University, Busan 609-735, Republic of Korea \\ 2 GIS Strategic Planning Department, GIS United Inc., Seoul 120-760, Republic of Korea \\ 3 Department of Geographical Information System Engineering, Namseoul University, Cheonan 331-707, Republic of Korea \\ ${ }^{4}$ School of Computer Science and Engineering, Seoul National University, Seoul 151-721, Republic of Korea \\ 5 Department of Environmental Education, Suncheon National University, Suncheon 540-742, Republic of Korea \\ ${ }^{6}$ Nakdong River Environment Research Center, NIER, Goryong 717-807, Republic of Korea \\ 7 Department of Environmental Science and Engineering, Kyunghee University, Yongin 446-701, Republic of Korea
}

Received 2 September 2010; Accepted 5 March 2011

\begin{abstract}
Stream restoration is an important process affecting the ecological health of stream ecosystems. There have been numerous cases of restoration, dealing with either structural or biological changes. In Korea, most restoration projects have merely dealt with improving hydrological characteristics or water quality; however, in recent years the improvement of ecological characteristics has been an increasing focus for restoration projects. In this study, we utilized data collected from 5675 stream sites in May 2007 to discover general patterns of anthropogenic modification in Korean streams. The survey results after application of the stream modification index (SMI; presence or absence type; high scores indicate more disturbed) provided a general distribution of disturbed/undisturbed streams or rivers in the watershed. We then compared the level of modification with the socio-geographical patterns (population, land coverage, elevation, and slope) for the watershed. The results show that streams in highly populated areas suffered from human modification compared with other well-preserved stream sites. In metropolitan cities, urbanized areas had positive relationship as identified by a high SMI. On the other hand, agricultural land cover identified an SMI increase for lowland river area. In general, mountainous streams possessed a better status in stream morphology due to different land-cover patterns (i.e., mainly forested area); however, some mountainous areas were impacted by concentrated summer rainfall. We could distinguish the forcing variables (i.e., land use pattern) for the disturbed streams through a comparison between the SMI and geographical information; the SMI application was able to identify areas of high necessity for restoration.
\end{abstract}

Key words: Stream modification index / Korean streams restoration / geographic information system (GIS) / land coverage / population density

\section{Introduction}

Ecological restoration can be defined as the return of an ecosystem to a close approximation of its condition prior to disturbance, and should be a holistic process that is not achieved through the isolated manipulation of individual elements (National Research Council, 1992). The objective of stream and river restoration is to remove current anthropogenic disturbance factors from the systems and create more natural stream systems that integrate every component (e.g., habitat and biological entities) within the

\footnotetext{
*Corresponding author: 1ter.ecoinfo@gmail.com
}

watershed. There are various types of disturbance observed in stream systems such as levee and dike strengthening and improvements, channelization, water quality deterioration caused by the increase of artificial structures in the catchment, etc. (Jeong et al., 2010a). The modification of habitat including streams brings out not only the degradation of the landscape but also the loss or degradation of natural habitat characteristics leading to a decrease in biodiversity (Mucher et al., 2009; Utz et al., 2009). Therefore, a stream restoration project is not merely recovering or recreating previous physical structure according to societal requests, but must consider ecological integration residing in the recovered structure. Ecological 
restoration is the re-establishment of processes, functions, and related biological, chemical, and physical linkages between ecosystems; it is the act of repairing damage resulting from human activities (Kauffman et al., 1997).

Stream restoration has to be comprehensive in ecological concept and requires understanding of the wider ecological space. Kauffman et al. (1997) insisted that stream restoration needs to be implemented at landscape or watershed perspectives, and emphasizing in-stream components (e.g., water channel recovery) is not recommended. A comprehensive literature review provided by Roni et al. (2002) showed that many stream restoration projects focused on specific site recovery, and they also suggested figuring out ecological processes in the watershed and ensuring connectivity between the specific sites for restoration and watershed to increase efficiency of restoration. Therefore, the connection between the watershed and streams is the most important, and the information for priority determination of stream restoration in watershed has to consider this harmony. From this point of view, pattern discovery at the catchment or regional level should occur prior to in-depth investigation with regard to those structural characteristics, to figure out the priority of restoration in a country or region. Usually, this necessity would be expressed by increasing habitat diversity, removing artificial structures, or reviving connectivity between streams and land. Patterns found during the regional search will provide guidance for detecting those areas with the highest priority of restoration.

River systems in Korea are good examples from the viewpoint of surveying present disturbances in stream ecosystems. Large dams are manipulating the water flow in the rivers, and even estuarine barrages are controlling water flow and saline intrusion, which result in division of brackish area into fresh and seawater areas (Joo et al., 1997). The levee was strengthened due to tight land use pattern, and stream systems have been seriously controlled especially for water flow management (Korea Environment Institute, 2008). Since 1960s, the Korean government determined water management policy on the increase of productivity, recognizing streams not for habitat but for water pathway, and numerous streams were physically modified (Son and Jeon, 2003). In recent decades, this understanding has changed, and restoration and conservation of stream habitats is actively being undertaken. The restoration project implemented by the government, named the Four Rivers Restoration Project, is a good example in Korean stream ecosystem restoration activity.

Some indexing protocols have been proposed considering either biological or morphological characteristics of stream ecosystems since the 1980s (e.g., Karr, 1981; Rankin, 1989; Ladson et al., 1999). They were widely applied globally, and are currently recognized as appropriate for qualitative evaluation. In Korea, a stream naturalness index system proposed by Cho (1997) was popularly adapted for stream ecosystems, which was to some extent compatible with those worldwide adapted methodologies. Nevertheless, their applicability are excellent, criteria consisting each evaluation parameter are slightly subjective. Therefore, Jeong et al. (2010a) proposed a fast-applicable method with dichotomous parameters to detect artificially modified streams and catchments.

In this study, the stream modification index (SMI) as proposed by Jeong et al. (2010a) was applied to stream ecosystems throughout Korea. Currently, one of the issues in stream environment sciences in Korea is the evaluation of the health of stream ecosystems. This can be directly linked to stream restoration. Therefore, over 5600 stream sites were evaluated using the proposed SMI method, and how stream modification was distributed and what the forcing variables were for the status of stream modification in Korean region are also under discussion.

\section{Methods}

\section{Study sites}

We established a total of 5675 sites in streams distributed in the four river watersheds (number of sites in each watershed: Han River, 1702 sites; Nakdong River, 1653; Geum River, 1218; Yeongsan-Seomjin Rivers, 1102; Fig. 1). We collected the stream information from the Water Management Information System (WAMIS; http:// www.wamis.go.kr) as maintained by the Ministry of Land, Transport and Maritime Affairs (MLTMA) of Korea. WAMIS uses four categories of stream level classification, such as national river (mostly consists of 5th-9th order streams), regional 1st- and 2nd-level streams (1st-7th and 1 st-6th orders, respectively), and miscellaneous tiny-scale streams (mostly 1st-3rd order). In this study, all streams and rivers belonged to those categories that were regarded as the survey targets, and mostly the first three categories were observed.

The stream site selection process was as follows (after Jeong et al., 2010a). The first site in every stream was established $2 \mathrm{~km}$ upstream from its estuarine area when it flowed to sea, or from the confluence toward the same- or higher-order streams. The distance between sites was $10 \mathrm{~km}$ for both national and regional 1st-level streams, and $5 \mathrm{~km}$ for regional 2nd-level streams from the first site of the streams. If the length of a stream was shorter than $5 \mathrm{~km}$, then we established only one site $2 \mathrm{~km}$ upstream of the estuarine area or confluent point (mostly for regional 2nd-level streams).

The Korean islands such as Jeju and other small islands distributed around the southwestern coast were not included in the survey because they do not belong to the four major river systems. In addition, some streams, which were close to the border between South and North Korea (which includes the demilitarized zone), were not sampled due to restricted access and security.

\section{Field survey and data preparation}

SMI is a presence-absence (dichotomous) survey evaluating the degree of artificial modification at study 


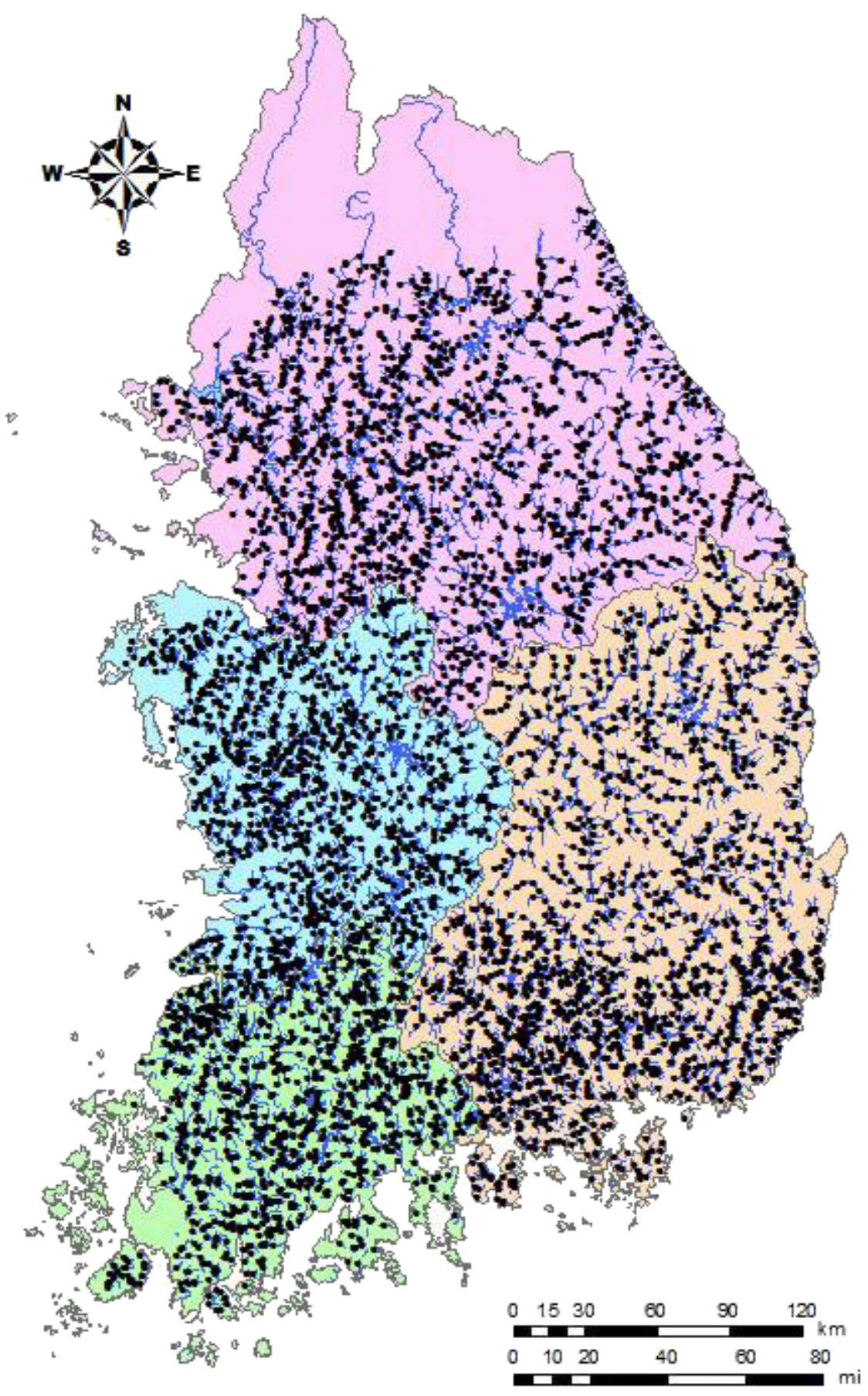

Fig. 1. Map of the study sites in Korea.

sites (Jeong et al., 2010a). This tool consists of 12 parameters comprising three factors such as water channel, land use pattern, and levee status (Table 1). The site survey was conducted over a $500 \mathrm{~m}$ span, i.e., $250 \mathrm{~m}$ up and downstream from the central coordinates of each survey point, respectively. The lateral boundary was $1000 \mathrm{~m}$ (500 m distance from each channel edge). We recorded the geographical locations in the WGS 84 geographical system to process the survey data into the geographical information system (GIS) database. If sites were covered by road or reclaimed, all modification parameters were marked as 1 because those sites can be recognized as "dead" stream sites from an ecological point of view. We calculated the final score for each site (i.e., the SMI score; maximum 12, minimum 1) by summing the twelve parameters' scores. For detailed information about the SMI system, its application method to study sites, and quality control (QC) programs, readers should consult Jeong et al. (2010a). The field survey was conducted in May 2007 by 18 teams specialized in freshwater ecology. 
Table 1. List of parameters applied to the stream sites during the field survey (after Jeong et al., 2010a).

\begin{tabular}{|c|c|c|c|c|}
\hline $\begin{array}{l}\text { Characteristics } \\
\text { factors }\end{array}$ & \multicolumn{2}{|c|}{ Characteristics } & nodification (presence, & \\
\hline Water channel & Weirs & Channelized & $\begin{array}{c}\text { Materials abstraction } \\
\text { (sand, gravels, etc.) }\end{array}$ & $\begin{array}{l}\text { Bridge, road, } \\
\text { levee construction }\end{array}$ \\
\hline Land use & Agriculture & Parks & Residential & Industrial \\
\hline Levee & Riprap & Stone piling & Concrete & $\begin{array}{l}\text { Mixed (more than two } \\
\text { at once) }\end{array}$ \\
\hline
\end{tabular}

\section{Analysis using GIS}

We used three socio-geographical datasets in the analysis of SMI distribution pattern. First, land coverage database for Korea was obtained from the Korean Ministry of Environment. This database consisted of seven categories (23 sub-categories), of which we utilized two major categories, urbanized and agricultural area, to explore human-involved disturbance of the stream's physical characteristics. For urbanized areas, we used residential and industrial coverage information, and for agricultural information, rice paddy and farmland coverage information was used. The second geographical information dataset was a digital elevation model (DEM) for the investigation of relationship between elevation and SMI score distribution. The third socio-information dataset was human population. The population data were obtained from Statistics Korea, and GIS United Inc., a GIS consulting company in Korea reprocessed this dataset.

In addition to exploring the relationship between SMI and socio-geography, we also considered rainfall distribution over Korea. Daily rainfall data at 76 weather stations, maintained by the Korea Meteorological Administration, were obtained, and we calculated the annual average rainfall amount at those stations. In order to compare rainfall distribution and SMI scores, we applied interpolation by the Kriging method to the 76 annual average rainfall dataset.

We utilized two types of spatial data analysis methods in this study. The first was the creation of a density map to discover the general pattern of SMI score distribution. Stream sites were not evenly distributed in Korea because a larger number of streams were found in mountainous watershed areas; therefore, we used $5 \mathrm{~km} \times 5 \mathrm{~km}$ square cells. By means of spatial joining between the square cells and the study sites located within each cell, we calculated the average values of SMI scores of each square cell. This type of work can reduce bias of SMI scores compared with the density of the study sites. These averaged scores were given to the center points of the cells, and we produced a density map of averaged SMI scores. Using this density map, we explored areas containing highly modified streams.

The second spatial analysis was designed to discover significant groups of cells in Korea. A spatial autocorrelation analysis (using Moran's I) was applied to the cell information. In contrast to general statistics, which assume every event to be isolated from each other, each spatial component is believed to be related (Legendre, 1993). This is the first law of geography, proposed by Waldo Tobler (Tobler, 1970), described as "Everything is related to everything else, but near things are more related than distant things." Spatial autocorrelation is therefore useful to display correlated components for a space in terms of a certain parameter, which can provide information of clusters (i.e., groups of the components) based on spatial autocorrelation. In this study, we used the averaged SMI scores for the cells during spatial autocorrelation process, and compared them with the density map. This comparison enabled us to discover areas that are significantly correlated in terms of their level of modification or their preservation as identified by their SMI scores. All spatial analysis was implemented under GIS environment based on ArcGIS 9.2.

\section{Results}

\section{Distribution patterns of SMI scores}

Figure 2 illustrates the number of study sites and square cells according to their SMI scores obtained from field survey. The largest number of study sites had scores of 3 and 4, and there was a distinct increasing tendency in the number of sites as the score increased to 3 or 4 (Fig. 2a). More than $90 \%$ of the study sites had scores of less than 5 (93.9\% of total sites). This pattern was similar to the distribution pattern of averaged SMI score in cells (Fig. 2b).

The cells with high SMI scores (i.e., disturbed) were densely distributed in the regions where large metropolitan cities were located (area in orange to red color), while low SMI scores were found in the upper reaches of river systems (area in green color; Fig. 3a). When we applied spatial autocorrelation to the cell-based SMI spatial database, global Moran's I was 0.299 ( $Z=41.78$, $P<0.001)$ which indicated that the cells were strongly clustered according to SMI scores. The application of the results of a local Moran's I analysis is depicted in Figure $3 \mathrm{~b}$. Among those areas showing high or low density of SMI scores, the cells located in two metropolitan cities' area (i.e., Seoul and Busan) and the eastern mountainous region had significant autocorrelation with cells close to each other (groups I, IV, and V; Fig. 3a). Local autocorrelation analysis also provided areas with low SMI scores (i.e., relatively not disturbed), which were located in upper-to-middle reaches of the Han River 

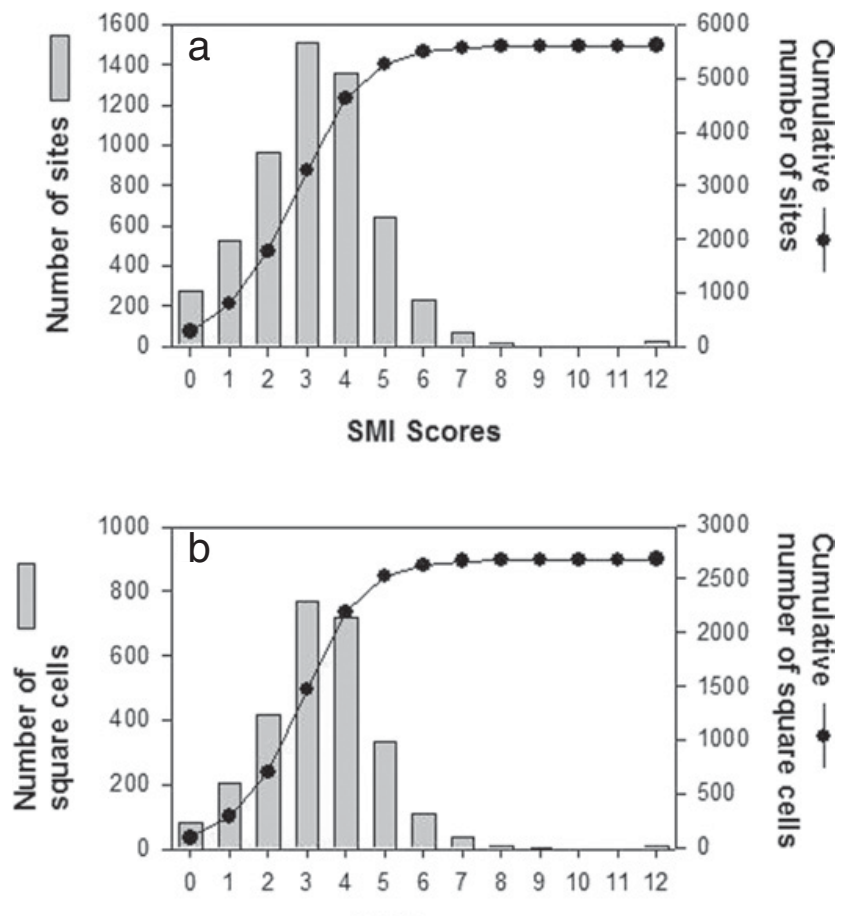

SMI Scores

Fig. 2. Histograms showing distribution pattern of study sites and square cells in accordance with SMI scores. (a) Number of study sites and (b) number of square cells.

and the Nakdong River watersheds (groups II and III; Fig. 3a).

\section{Relationship between human population, rainfall, and SMI}

Figure 4 illustrates the comparison between average SMI scores for cells, the density of human population, and the annual average rainfall distribution. For those areas showing statistical significance (i.e., groups I-V), there was a positive relationship between human population and the average SMI score (Fig. 4a). Low population density was found for areas possessing groups II and III, which had relatively low SMI scores. However, areas with strongly disturbed streams (i.e., groups IV and V) were moderately to heavily populated.

Group I (i.e., cells in mountainous area) had relatively high SMI scores even though human population density was not high relative to other groups. Figure $4 \mathrm{~b}$ is a map of rainfall distribution (average annual rainfall from 2002 to 2007), which might provide evidence for stream disturbance. The area of group I almost overlapped the area with highly concentrated rainfall (i.e., northeastern area). Among the remaining areas with insignificant spatial autocorrelation, streams in western area were relatively modified (Fig. 3), and the population density was moderately high compared to the other areas with low population densities and low SMI scores.

\section{Detection of area with disturbed streams in Korea}

We compared SMI scores, elevation, and land coverage to discover human-induced factors that result in stream modification. Figure 5 provided the density maps of that information, and the land coverage information as well as elevation was differently related to those areas with relatively high SMI scores (solid lined area a-f; Fig. 5a). Generally, low SMI scores were found in areas with higher elevations, and relatively high SMI scores were detected in lowland areas (Figs. 5a and 5b). Among the six areas distinguished based on SMI score, the density of urbanized land cover dominated the metropolitan area (Figs. 5c and 5d), while agricultural impacts were thought to affect stream modification in the southern and western lowland area (areas c-e; Figs. 5e and 5f).

Even though the typical SMI scores were low in streams at higher elevations, the SMI score in the area $\mathrm{f}$ was relatively high. The dominant land coverage pattern for this area was farmland (Fig. 5f), and compared to the aforementioned results (i.e., rainfall distribution), this area was affected by human-induced disturbance and rainfall distribution (Fig. 5f).

\section{Discussion}

\section{Human distribution and stream modification in Korea}

From the results of this study, it can be summarized that anthropogenic stream modification in Korea is primarily affected by the distribution of human society, which could be translated by land coverage pattern. Stream modification primarily occurred in stream segments or reaches where the surrounding environment has to be protected for human use (e.g., levee construction), water resources have to be stored (e.g., weir installation), or extensive erosion has to be prevented (e.g., water channel modification). Streams in the area with high population density, maintained a set of evenly disturbed stream morphological characters. This was true for metropolitan cities and highly urbanized areas. However, areas where agricultural land coverage was dominant also produced relatively largely disturbed stream conditions.

The relationships between the development and growth of human society, and stream environmental characteristics have been discussed in previous studies. Land use pattern was identified as the main factor determining environments and ecological characters. Strongly developed human society often brought about the gradual expansion of urbanized or agricultural land (Allan et al., 1997), and human-induced land use patterns resulted in altered hydrology, sediment transport, and even biodiversity, compared with native forests (Allan et al., 2002). This pattern was also be found in Roth (1994), who suggested that agricultural area expansion affected habitat quality and biological integration in streams. When we regard the level of stream modification investigated in this study as one component of stream ecosystem degradation, 

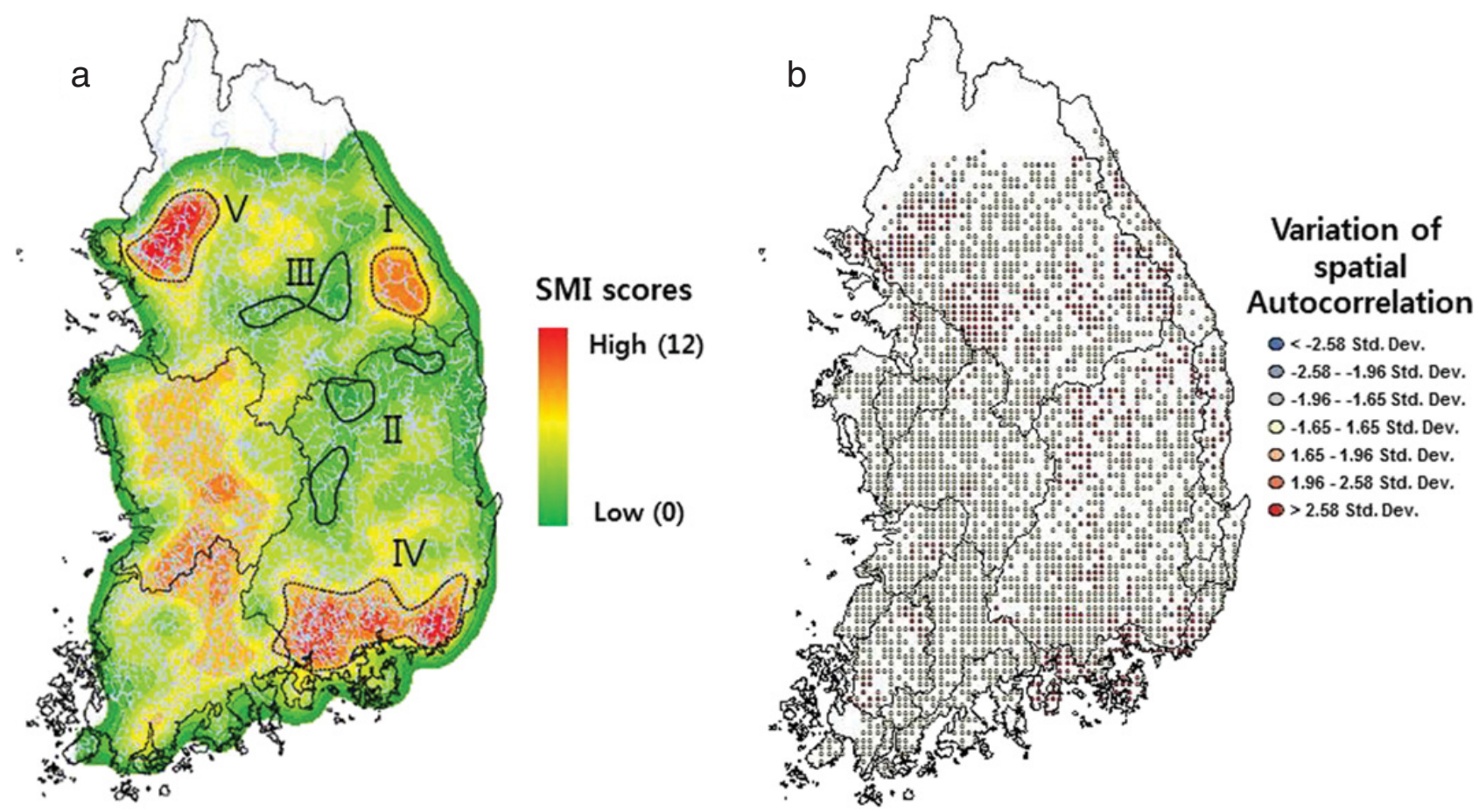

Fig. 3. SMI distribution and spatial autocorrelation results. (a) Density map for SMI scores in Korean region and (b) distribution of square cells with significant spatial autocorrelation.
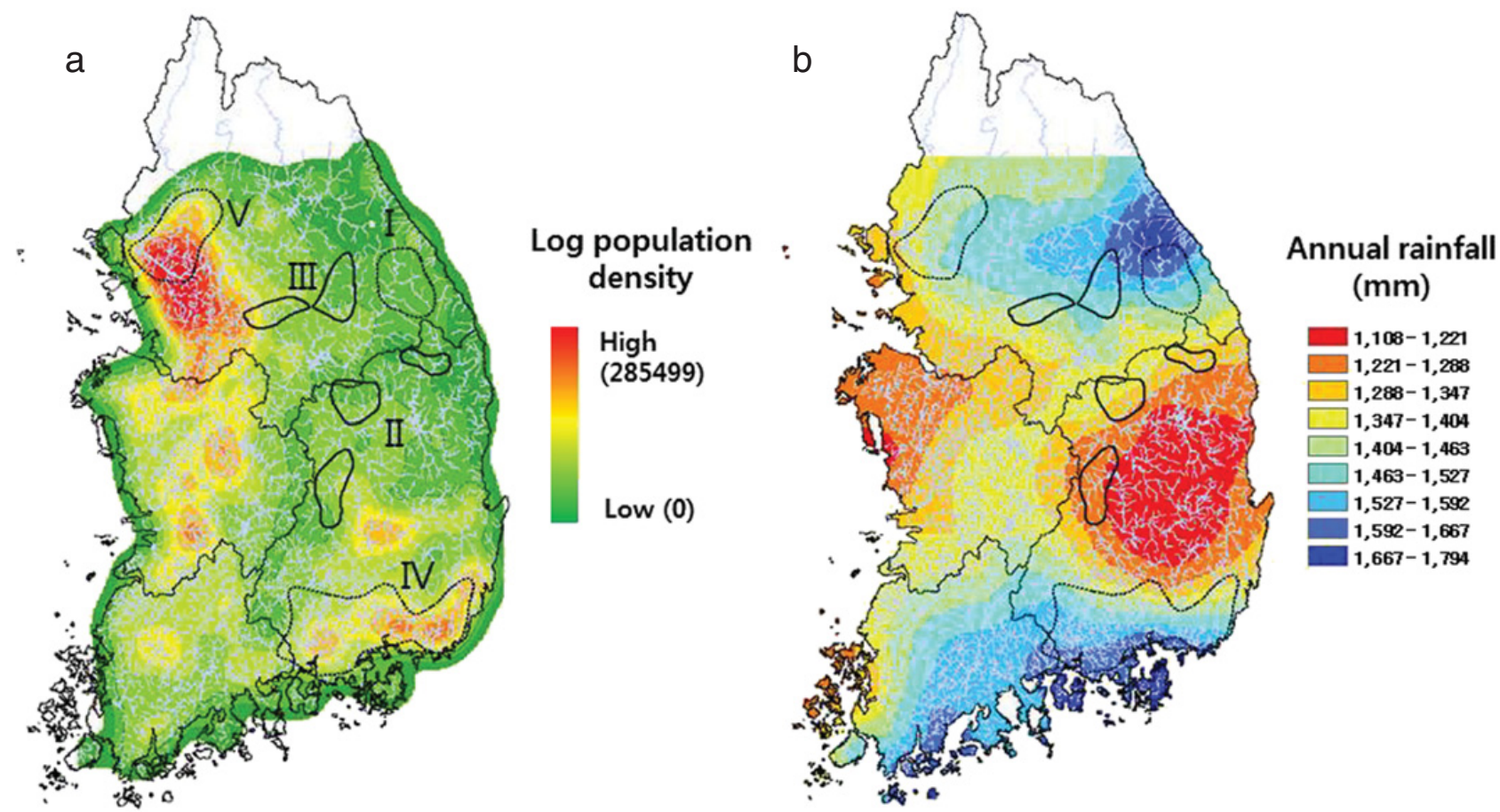

Fig. 4. Distribution of human population and rainfall in Korean region. (a) Density of human population in logarithm and (b) interpolated rainfall amount in Korea (2002-2007).

the positive relationship between SMI scores, human population, urbanization, and agricultural area expansion can be explained from this point of view. Looking more directly at the comparison between SMI and socio-geography, Jeong et al. (2010a) discussed how the scores of SMI had a significant relationship with the sociogeographical database. However, the samples used in this study exceeded the comprehensiveness of that research 

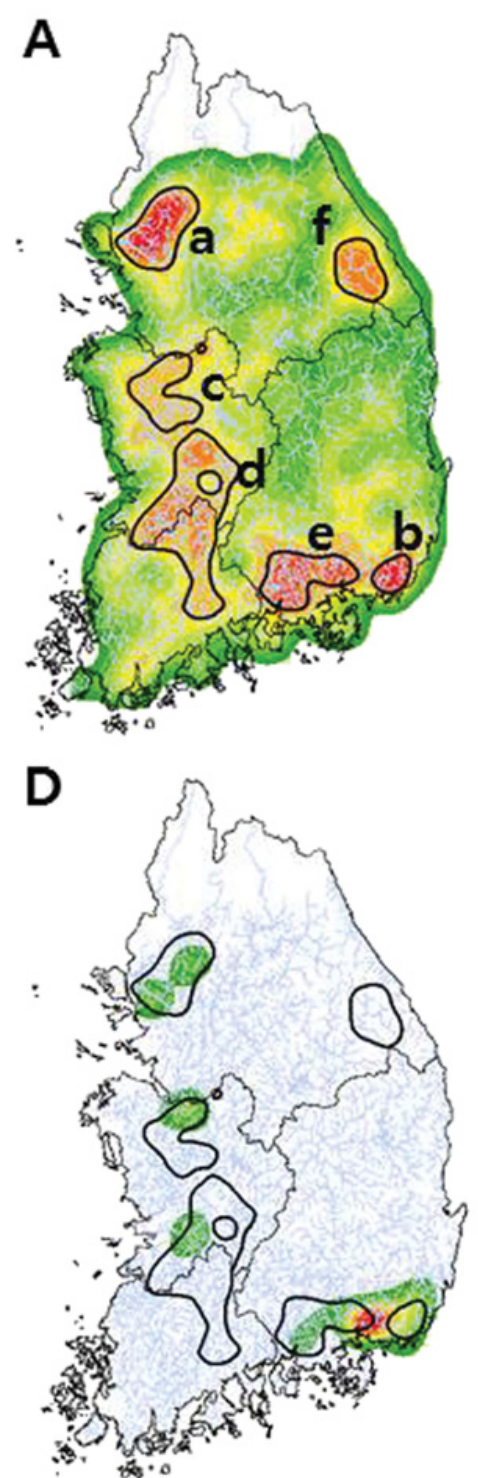
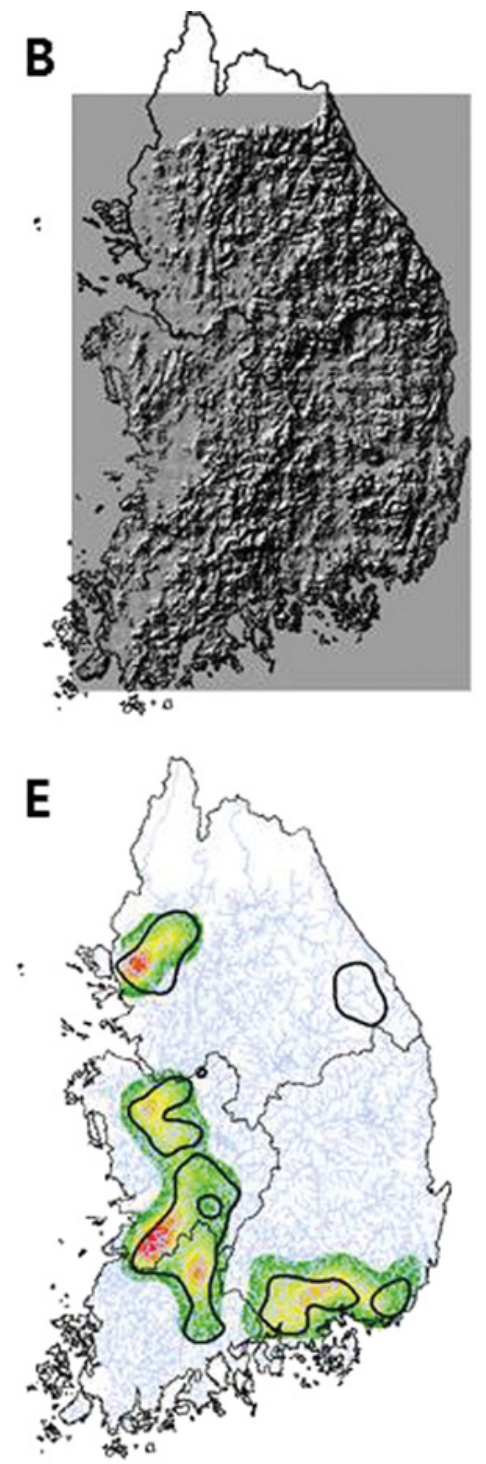
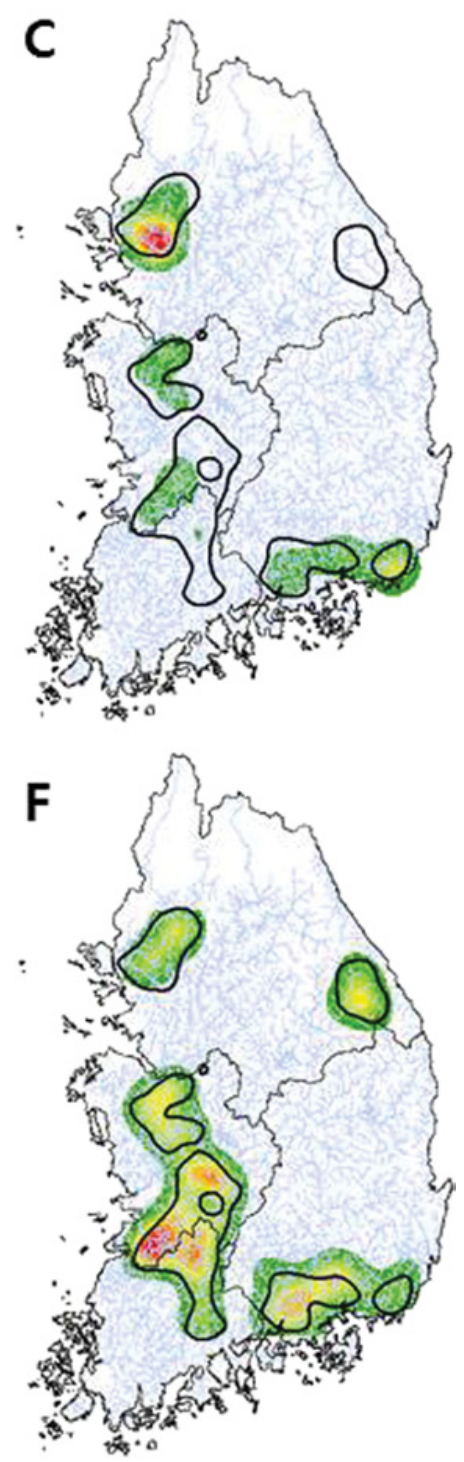

Fig. 5. Relationship between SMI scores, elevation, and human-induced land coverage. (a) SMI score, (b) hill-shade map of Korea, (c) density of residential area, (d) density of industrialized area, (e) density of rice paddy, and (f) density of farmland.

more than 3-fold, and therefore a regional generalization by means of spatial analysis was possible. In addition, the area affected by anthropogenic modification of streams was supported in this study, which can provide basic information for stream restoration projects. Most previous studies that have dealt with land use and stream characteristics were based on geographical information when the studies covered comparatively large areas. Only a few studies have looked at small areas investigating both field status and map-based information. The field survey results of this study were from almost a complete enumeration, and the field information was compared with geography. Therefore, those patterns found in this study can be used to elucidate the previous information on a relatively larger spatial scale. When we apply the SMI system to time-series data, the continuous change in stream status can be determined.

\section{Stream restoration strategy and SMI application}

Water resource management in Asia is an important issue because many streams and rivers experience flooding events due to concentrated summer rainfall. Numerous weirs as well as dams have been constructed in this region to provide stable water resources to the basin residents (Tharme, 2003). In Korea, it has been reported that there are more than 18000 weirs and dams present in stream systems (Park et al., 1999), which would provide evidence of the difficulty in water resource management within the country. The other problem caused by the concentrated rainfall is direct damage from flooding. The highest frequency of damage to human society reported in Asia is because of flash floods (Jonkman, 2005), which often led to levee reinforcement to prevent flood damages (MOE/ NIER, 2008). The increasing probability of strong floods 
in the region (Dutta and Herath, 2004; Jeong et al., 2010b; Jeong et al., to appear) might press stream management strategy developers to seriously control water flow against possible damage from flooding. In this point of view, the anthropogenic modification of stream or river shape is inevitable.

The Korean government is well aware of the environmental necessity and ecological value of stream restoration. They are collecting large amounts of information regarding the status of disturbed lotic systems via environmental research programs such as the Stream Health Evaluation project, and the Korean National Long-Term Ecological Research program. The information from those projects can redirect the problem of stream and river restoration that the Korean government has adopted: i.e., hydrological efficiency, such as dredging sediment contaminants and installing locks and dams (Joo et al., 2007). The SMI application in this study can identify those areas where stream morphology requires restoration or rehabilitation. However, the generalization of habitat/stream quality based on the SMI is not supported by local characteristics (Jeong et al., 2010a); and therefore an in-depth diagnosis for restoration projects is strongly necessitated.

Stream and river restoration in Korea has to be multidimensional as well as sequential. For the sequential process, removal of the disturbance factor should be followed by active restoration of necessary ecological structure (Kauffman et al., 1997), and furthermore, continuous monitoring for the effectiveness of restoration has to be implemented that have not been performed in most restoration projects (Selvakumar et al., 2010; Whiteway et al., 2010). Multi-dimensional restoration planning can be found when observing the biodiversity perspective: i.e., not only biological components but also habitats and connectivity need to be considered simultaneously, and the strategies for restoration or conservation of habitats should be distinguished from each other (Roni et al., 2002). Palmer et al. (2005) proposed some standards for the assessment of restoration results when focusing on the stakeholders' benefit, the scientific contribution, and the ecological improvement, which will be able to address the advantages and disadvantages for current restoration practices in Korea. The application of SMI to streams investigated in this study at a regular interval will provide useful information for the generalization of regional stream status, from this point of view.

\section{Conclusion}

In this study, a total of 5675 stream sites in Korea were surveyed in May 2007 to conduct a comprehensive evaluation of the degree of anthropogenic stream modification. The SMI system was developed for monitoring stream health or habitat naturalness (presence or absence type). The monitoring results provided a general distribution of disturbed/undisturbed streams or rivers in the river basin, and the degree of modification was closely related to socio-geographical patterns. Importantly, highly populated areas were relatively more disturbed compared to other more well-preserved stream sites. In addition, the relationship between stream modification and land coverage pattern was different relative to the locality. In areas where metropolitan cities were located, the urbanized area that had higher SMI scores were more developed. Comparatively, lowland river areas, which are affected by agricultural land cover, also had relatively high SMI scores. Some mountainous areas were believed to be impacted by summer-concentrated rainfall (flooding) even though this area was highly elevated and land cover pattern was different from urbanized or agricultural areas. A simple and fast survey method such as SMI could be used to explore areas that require restoration, and the major influencing factors could be derived from sociogeographical and meteorological information.

Acknowledgements. This study was financially supported by the Ministry of Environment and the National Institute of Environmental Research (Korea), and the results of this study form part of the "Survey and Evaluation of Aquatic Ecosystem Health in Korea." The authors would like to thank all of the field survey members who are currently involved in the Stream Health Evaluation project, managed by the Ministry of Environment and the National Institute of Environmental Research, in Korea, for their invaluable comments in the development of the SMI tool and field monitoring. We also thank reviewers for their constructive comments in improving the manuscript. A part of funding for this paper was provided by Namseoul University.

\section{References}

Allan D., Erickson D. and Fay J., 1997. The influence of catchment land use on stream integrity across multiple spatial scales. Freshwater Biol., 37, 149-161.

Allan J.D., Brenner A.J., Erazo J., Fernandez L., Flecker A.S., Karwan D.L., Segnini S. and Taphorn D.C., 2002. Land use in watersheds of the Venezuelan Andes: a comparative analysis. Conserv. Biol., 16, 527-538.

Cho Y.H., 1997. A study on evaluation method of stream naturalness for ecological restoration of stream corridors. J. Korean Inst. Landsc. Arch., 25, 2073-2081 (in Korean with English summary).

Dutta D. and Herath S., 2004. Trend of floods in Asia and a proposal for flood risk management with integrated river basin approach. Paper presented at the Proceedings of the Second International Conference of Asia-Pacific Hydrology and Water Resources Association, Singapore.

Jeong K.-S., Hong D.-G., Byeon M.-S., Jeong J.-C., Kim H.-G., Kim D.-K. and Joo G.-J., 2010a. Stream modification patterns in a river basin: field survey and self-organizing map (SOM) application. Ecol. Inform., 5, 293-303.

Jeong K.-S., Kim D.-K., Shin H.-S., Kim H.-W., Cao H., Jang M.-H. and Joo G.-J., 2010b. Flow regulation for water quality (chlorophyll a) improvement. Int. J. Environ. Res., 4, 713-724.

Jeong K.-S., Kim D.-K., Shin H.-S., Yoon J.-D., Kim H.-W. and Joo G.-J., to appear. Impact of summer rainfall on the 
seasonal water quality variation (chlorophyll a) in the regulated Nakdong River. KSCE J. Engineer.

Jonkman S.N., 2005. Global perspectives on loss of human life caused by floods. Nat. Hazards, 34, 151-175.

Joo G.J., Kim H.W., Ha K. and Kim J.K., 1997. Long-term trend of the eutrophication of the lower Nakdong River. Korean J. Limnol., 30 (Suppl.), 472-480.

Joo G.-J., Shin H.-S., Kim S.-D., Kim J.-W., Kim H.-W. and Yoon S.-Y., 2007. Assessment for storage capacity of riverine wetlands in the Nakdong River during flood event (No. 07-09), Nakdong River Water Environment Research Center, Goryeong (in Korean).

Karr J., 1981. Assessment of biotic integrity using fish communities. Fisheries, 6, 21-27.

Kauffman J.B., Beschta R.L., Otting N. and Lytjen D., 1997. An ecological perspective of riparian and stream restoration in the western United States. Fisheries, 22, 12-24.

Korea Environment Institute, 2008. A small stream management plan to protect the aquatic ecosystem, Korea Environment Institute, Seoul (in Korean).

Ladson A.R., White L.J., Doolan J.A., Finlayson B.L., Hart B.T., Lake P.S. and Tilleard J.W., 1999. Development and testing of an index of stream condition for waterway management in Australia. Freshwater Biol., 41, 453-468.

Legendre P., 1993. Spatial autocorrelation: Trouble or new paradigm? Ecology, 74, 1659-1673.

MOE/NIER, 2008. Survey and evaluation of aquatic ecosystem health in Korea, The Ministry of Environment/ National Institute of Environmental Research, Korea (in Korean).

Mucher C.A., Hennekens S.M., Bunce R.G.H., Schaminee J.H.J. and Schaepman M.E., 2009. Modelling the spatial distribution of Natura 2000 habitats across Europe. Landscape Urban Plan., 92, 148-159.

National Research Council, 1992. Restoration of Aquatic Ecosystems: Science, Technology and Public Policy, Washington, DC.

Palmer M.A., Bernhardt E.S., Allan J.D., Lake P.S., Alexander G., Brooks S., Carr J., Clayton S., Dahm C.N., Follstad Shah J., Galat D.L., Loss S.G., Goodwin P., Hart D.D., Hassett B., Jenkinson R., Kondolf G.M.,
Lave R., Meyer J.L., O’Donnell T.K., Pagano L. and Sudduth E., 2005. Standards for ecologically successful river restoration. J. Appl. Ecol., 42, 208-217.

Park S.-B., Lee J.-Y., Jang M.-H., Kim H.-W., Jeong J.-M., Kim J.-W. and Joo G.-J., 1999. Water quality and phytoplankton community dynamics in a weir reach of the Yangsan Stream (1993-1996). Kor. J. Limnol., 32, 331-340 (in Korean with English summary).

Rankin E.T., 1989. The Qualitative Habitat Evaluation Index: (QHEI); Rationale, Methods, and Application, Environmental Protection Agency.

Roni P., Beechie T.J., Bilby R.E., Leonetti F.E., Pollock M.M. and Pess G.R., 2002. A review of stream restoration techniques and a hierarchical strategy for prioritizing restoration in Pacific Northwest watersheds. N. Am. J. Fish Manage., 22, 1-20.

Roth N.E., 1994. Land Use, Riparian Vegetation, and Stream Ecosystem Integrity in an Agricultural Watershed, The University of Michigan.

Selvakumar A., O'Connor T.P. and Struck S.D., 2010. Role of stream restoration on improving benthic macroinvertebrates and in-stream water quality in an urban watershed: case study. J. Environ. Eng., 136, 127-139.

Son M.W. and Jeon Y.-G., 2003. Physical geographical characteristics of natural wetlands on the downstream reach of Nakdong River. J. KARG, 9, 66-76 (in Korean with English summary).

Tharme R.E., 2003. A global perspective on environmental flow assessment: emerging trends in the development and application of environmental flow methodologies for rivers. River Res. Appl., 19, 397-441.

Tobler W., 1970. A computer movie simulating urban growth in the Detroit region. Econ. Geogr., 46, 234-240.

Utz R.M., Hilderbrand R.H. and Boward D.M., 2009. Identifying regional differences in threshold responses of aquatic invertebrates to land cover gradients. Ecol. Indic., 9, 556-567.

Whiteway S.L., Biron P.M., Zimmermann A., Venter O. and Grant J.W.A., 2010. Do in-stream restoration structures enhance salmonid abundance? A meta-analysis. Can. J. Fish. Aquat. Sci., 67, 831-841. 